Images in...

\title{
Painless nodules over joints with ulceration
}

\author{
Apurva Khare, Rakesh Biswas \\ Department of Medicine, People's College of Medical Sciences, Bhopal, India
}

Correspondence to Rakesh Biswas, rakesh7biswas@gmail.com

\section{DESCRIPTION}

A 30-year-old male presented with swellings over left elbow, left ankle, base of the first meta-tarso-phalangeal joint of both feet (figures 1-3). He had ulcers over swelling of right meta-tarso-phalangeal joint and dorsum of same foot since 3 months. He also had polyuria and low-grade fever since 6 months. There was a chalky white discharge from the ulcers, which on examination under polarised microscope showed large number of needle shaped crystals with negative birefringence. Patient had normal I.Q level, there was no history suggestive of mutilating behaviour, morning stiffness, photosensitivity, genitourinary complaints, red eye, or Raynaud's phenomenon. Patient's elder brother had history of recurrent nephrolithiasis (He was not available for serum uric acid measurements). His maternal uncle died at young age due to renal failure. He never had any attack of typical gouty arthritis. Patient became afebrile with use of oral paracetamol. When patient reported for the first time his baseline creatinine was $0.9 \mathrm{mg} / \mathrm{dl}$. He was started on tablet allopurinol $300 \mathrm{mg}$ once daily and 2 weeks after initiation of treatment patient's creatinine levels climbed to $1.3 \mathrm{mg} / \mathrm{dl}$. Allopurinol was discontinued, and he was started on tablet febuxostat and is still continued on this treatment with a creatinine value of $1 \mathrm{mg} / \mathrm{dl}$ at present. His serum uric acid has come down from 10.5 to $7.5 \mathrm{mg} / \mathrm{dl}$. The development of tophi in the absence of prior episodes of gouty arthritis is unusual. The first such patient was reported in $1965 .{ }^{1}$ Wernick et al presented six
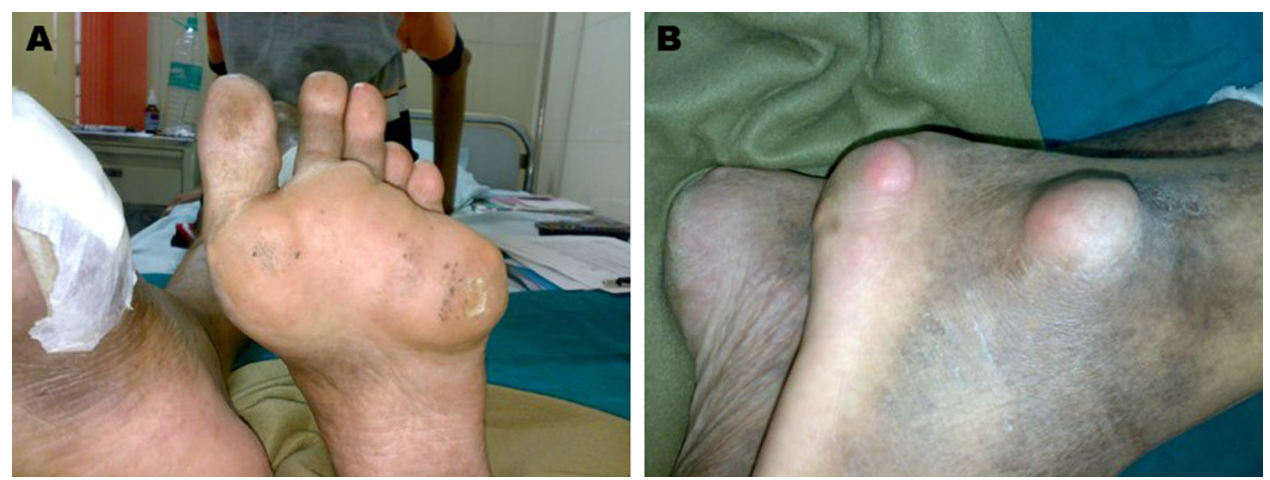

Figure 1 (A, B) Gouty tophus on left and right lower limbs.

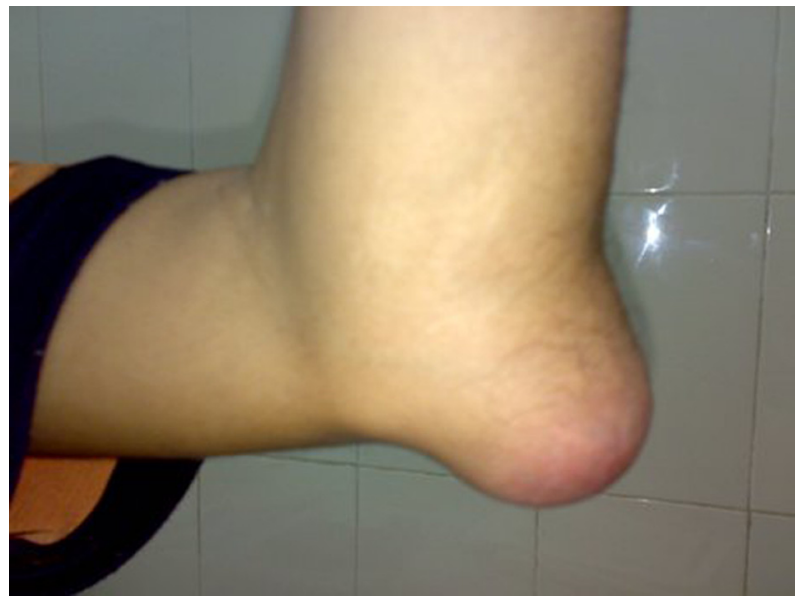

Figure 2 Gouty tophy on elbow.

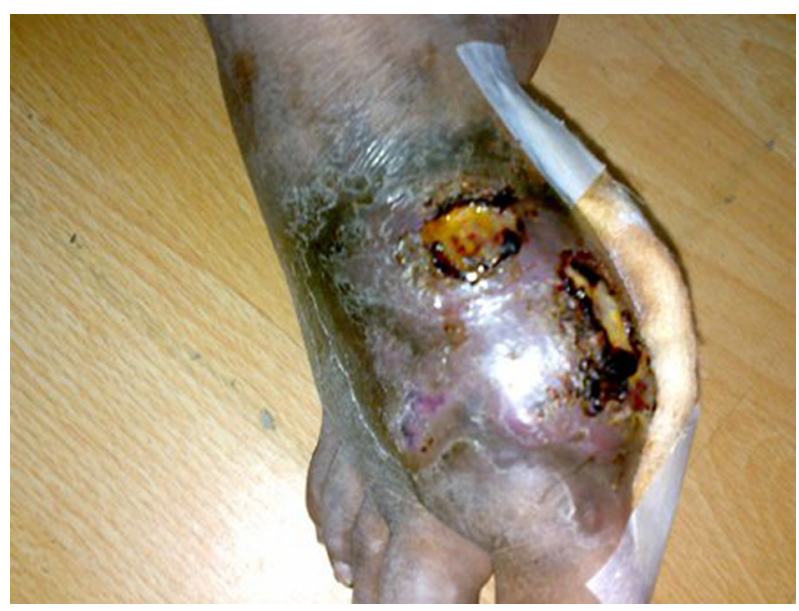

Figure 3 Infected tophi. 


\section{BMJ Case Reports}

such cases and reviewed 26 previously published cases and found that these patients differed from those with typical gout in that they were older, more likely to be women, and usually had predominant or exclusive finger involvement. ${ }^{2}$ Most had renal insufficiency and many were receiving an anti-inflammatory or diuretic. Our patient was a young male and did not have exclusive finger involvement. $\mathrm{He}$ did have mild renal insufficiency for which he was put on febuxostat as its pharmacokinetics and pharmacodynamics are not significantly altered in patients with moderate renal insufficiency. ${ }^{3}$ This case has been primarily submitted for the striking image of the gouty tophi.
Competing interests None.

Patient consent Obtained.

\section{REFERENCES}

1. Yu TF. Secondary gout associated with myeloproliferative diseases. Arthritis Rheum 1965;8:765-71.

2. Wernick R, Winkler C, Campbell S. Tophi as the initial manifestation of gout: report of six cases and review of the literature. Arch Intern Med 1992;152:873-6.

3. Reinders MK, Jansen TL. Management of hyperuricemia in gout: focus on febuxostat. Clin Interv Aging 2010;5:7-18.

This pdf has been created automatically from the final edited text and images.

Copyright 2011 BMJ Publishing Group. All rights reserved. For permission to reuse any of this content visit

http://group.bmi.com/group/rights-licensing/permissions.

BMJ Case Report Fellows may re-use this article for personal use and teaching without any further permission.

Please cite this article as follows (you will need to access the article online to obtain the date of publication).

Khare A, Biswas R. Painless nodules over joints with ulceration. BMJ Case Reports 2011;10.1136/bcr.07.2011.4548, date of publication

Become a Fellow of BMJ Case Reports today and you can:

- Submit as many cases as you like

- Enjoy fast sympathetic peer review and rapid publication of accepted articles

- Access all the published articles

- Re-use any of the published material for personal use and teaching without further permission

For information on Institutional Fellowships contact consortiasales@bmjgroup.com

Visit casereports.bmj.com for more articles like this and to become a Fellow 